\title{
PEMANFAATAN MEDIA TIK TOK SEBAGAI MEDIA DAKWAH BAGI DOSEN IAI SUNAN KALIJOGO MALANG
}

\author{
Sholihatul Atik Hikmawati1), Luluk Farida2) \\ 1), 2)IAI Sunan Kalijogo Malang \\ 1)sholihatulhikmaati@gmail.com, 2) $\underline{\text { lulukfarida05@gmail.com }}$
}

\begin{abstract}
Abstrak: Tik tok merupakan salah satu platform yang dimanfaatkan dosen untuk menyampaikan pesan dakwah kepada masyarakat secara luas agar menarik dan mudah diterima oleh mad'u. Ditengah digitalisasi area dakwah Islam harus fleksibel, mampu mengikuti perkembangan zaman, perkembangan umat dan budaya umat, harus dikemas dengan menarik. Ketika melihat situasi dan kondisi seperti ini, ternyata Tik tok begitu akrab dengan aktivitas keseharian mahasiswa maupun masyarakat pada umumnya terutama generasi milenial, bahkan tak sedikit yang setiap harinya pasti membuka Tik tok, dari sini da'i memanfaatkan Instagram sebagai media dakwah. Penelitian ini merupakan penelitian deskriptif dengan pendekatan kualitatif. Sampel penelitian ini adalah Dosen yang menggunakan aplikasi tik tok dalam menyampaikan dakwahnya. Sampel penelitian ditentukan secara random sampling, dimana peneliti memilih sampel dari populasi secara acak. Teknik pengumpulan data menggunakan metode observasi, angket, wawancara dan dokumentasi. Data yang diperoleh kemudian dianalisis secara deskriptif dengan cara reduksi data, penyajian data dan penarikan kesimpulan. Hasil penelitian diketahui bahwa : Tik tok memberikan banyak sekali manfaat sebagai media dakwah. Dalam memanfaatkan Tik tok sebagai media dakwah bagi Dosen, terdapat 2 macam bentuk pemanfaatan; 1) Pemanfaatan Tik tok sebagai media komunikasi, 2) Pemanfaatan Tik tok sebagai media dakwah. Kesimpulannya, Tik tok dapat dikatakan efektif sebagai media dakwah, jika digunakan dengan baik sesuai syariat Islam. Secara keseluruhan dakwah di Tik tok merupakan dakwah milenial mampu menciptakan dakwah yang innovatif yang mampu menarik perhatian followers untuk membagikan ke media sosial yang mereka miliki.
\end{abstract}

Kata kunci: Media, Tik tok, Dakwah Islam

Abstract: Tik Tok is one of the platforms used by lecturers to convey da'wah messages to the wider community so that it is attractive and easily accepted by mad'u. In the midst of digitalization, the area of Islamic da'wah must be flexible, able to keep up with the times, the development of the ummah and the culture of the people, it must be packaged attractively. When looking at situations and conditions like this, it turns out that Tik Tok is very familiar with the daily activities of students and the community in general, especially the millennial generation, even many of them are sure to open Tik Tok every day, from here preachers use Instagram as a medium of da'wah. This research is a 
descriptive study with a qualitative approach. The sample of this research is lecturers who use the tik tok application in delivering their da'wah. The research sample is determined by random sampling, where the researcher chooses a sample from the population randomly. Data collection techniques using observation, questionnaires, interviews and documentation. The data obtained were then analyzed descriptively by means of data reduction, data presentation and drawing conclusions. The results of the study show that: Tik Tok provides many benefits as a medium of preaching. In utilizing Tik Tok as a medium of preaching for lecturers, there are 2 types of utilization; 1) Use of Tik Tok as a medium of communication, 2) Use of Tik Tok as a medium of da'wah. In conclusion, Tik Tok can be said to be effective as a means of preaching, if it is used properly according to Islamic law. Overall preaching in Tik Tok is millennial preaching capable of creating innovative preaching that is able to attract the attention of followers to share on their social media.

\section{Keywords: Media, Tik Tok, Islamic Da'wah}

\section{PENDAHULUAN}

Secara etimologis, kata dakwah merupakan bentuk masdar dari kata yad"u (fi"il mudhari") dan da"a ( $f i " i l$ madli) yang artinya adalah memanggil (to call), mengundang (to invite), mengajak (to summer), menyeru (to propo), mendorong (to urge) dan memohon (to prray). ${ }^{1}$ Selain kata "dakwah", al-Qur'an juga menyebutkan kata yang memiliki pengertian yang hampir sama dengan "dakwah", yakni kata "tabligh" yang berarti penyampaian, dan "bayan” yang berarti penjelasan. Sedangkan secara terminology menurut M. Quraish Shihab, dakwah adalah seruan atau ajakan kepada keinsyafan atau usaha mengubah situasi kepada situasi yang lebih baik dan sempurna, baik terhadap pribadi maupun masyarakat. ${ }^{2}$ Sedangkan menurut peneliti dakwah merupakan suatu usaha yang dilakukan manusia secara sadar untuk mengingatkan hal-hal kebaikan dengan cara yang bijak dan menentramkan pada diri sendiri dan lingkungan sekitarnya pada khususnya. Dan khalayak luas pada umumnya.

Dakwah itu sendiri erat kaitannya dengan era digital yang berkembang pesat saat ini. Dimana informasi dalam genggaman tangan dengan media smartphone sudah menjadi bagian penting dari pola hidup masyarakat. Seperti dari hasil penelitian, menyatakan bahwa Negara-negara di Asia merupakan pengguna smartphone terbesar

\footnotetext{
${ }^{1}$ Awaludin Pimay, Paradigma Dakwah Humanis: Strategi Dan Metode Dakwah Prof. KH Saifuddin Zuhri (RaSAIL, 2005).

2 Dewi Thoharoh, "Strategi Dakwah M. Quraish Shihab Dalam Buku" Membumikan Al-Qur'an"'” (IAIN Walisongo, 2010).
} 
di dunia. ${ }^{3}$ Dengan fenomena inilah, Smartphone merupakan bagian dari kebiasaan masyarakat dari seluruh lapisannya. Seiring dari maraknya penggunaan telepon smartphone sebagai alat komunikasi, penggunaan telepon genggam tidak hanya sebatas sms dan berbicara melalui telepon tetapi juga fasilitas-fasilitas lainnya.

Contohnya Gmail yang dahulu merupakan satu-satunya sarana chatting di internet, sekarang fasilitas tersebut sudah berpindah ke dalam genggaman dan tidak harus berhadapan dengan layar komputer di rumah. Bahkan fitur ini dikembangkan sesuai dengan kebutuhan masyarakat misalnya google meet jika mereka ingin melakukan interaksi, gmail jika mereka menginginkan korespondensi, blogger jika mereka ingin mengekspresikan pasiionnya dalam media tulis bahkan dakwah. Contoh lain penggunaan media online adalah penggunaan media sosial seperti facebook. Facebook sejauh ini merupakan salah satu media dakwah yang prospektif dan efektif untuk berdakwah melalui tulisan. Tidak hanya tulisan, facebook juga menawarkan fitur-fitur unik, sederhana dan mudah dipahami, seperti fitur friend requests (ajakan pertemanan), notification (pemberitahuan), messages (pesan tertulis langsung kepada pemilik akun), recommended pages (merekomendasikan halaman), notes (catatan), photo album (album foto), status, comment (komentar) dan sebagainya. Semuanya merupakan fitur yang cukup mudah untuk digunakan, khususnya mengaplikasikan sebagai sarana syiar dakwah Islam. ${ }^{4}$

Maraknya media sosial berkembang dikalangan masyarakat luas. Maka peneliti disini akan focus pada salah satu media yang sedang tranding yaitu media Tiktok. Media ini banyak digunakan hampir semua lapisan masyarakat. Media ini dikemas secara sederhana namun lengkap sehingga mudah bagi pengguna untuk mengaplikasikannya. Media ini tak hanya menampilkan foto saja, namun juga video interaksi melalui tik tok live. Media penyampaian secara menarik melalui tik tok feed yang secara langsung bisa mendapatkan respon dari segenap follower yang dimiliki.

\footnotetext{
${ }^{3}$ Ita Musfirowati Hanika, "Fenomena Phubbing Di Era Milenia (Ketergantungan Seseorang Pada Smartphone Terhadap Lingkungannya)," Interaksi: Jurnal Ilmu Komunikasi 4, no. 1 (2015): 42-51. ${ }^{4}$ Yosieana Duli Deslima, "Pemanfaatan Instagram Sebagai Media Dakwah Bagi Mahasiswa Komunikasi Dan Penyiaran Islam UIN Raden Intan Lampung” (UIN Raden Intan Lampung, 2018).
} 
Adapun Da'I juga dituntut untuk mengemas pesan dakwah secara kreatif sehingga sampai ditangan Mad'u dengan cara yang rileks dan menyenangkan.

\section{Tik tok: Sejarah dan Fungsi}

Aplikasi Video TikTok kini sudah menjalar ke semua kalangan di Indonesia. Para Politisi, Pejabat, Artis dan Masyarakat, beramai-ramai untuk membuat video dalam Aplikasi Video TikTok. TikTok sendiri adalah salah satu aplikasi yang sangat digandrungi millennials, generasi $\mathrm{Z}$ dan anak-anak kecil jaman now. Aplikasi ini memberikan special effects unik dan menarik yang dapat digunakan oleh penggunanya dengan mudah sehingga dapat membuat video pendek. Aplikasi sosial video pendek ini memiliki dukungan musik yang banyak sehingga penggunanya dapat melakukan performanya dengan tarian atau gaya bebas.

Zhang Yiming, merupakan lulusan software engineer dari Universitas Nankai mendirikan perusahaan teknologi ByteDance pada Maret 2012. Lewat perusahaannya inilah Yiming mengembangkan aplikasi TikTok. ${ }^{5}$ Awalnya ByteDance meluncurkan aplikasi berita, Toutiao yang kini menjadi salah satu yang terbesar di Cina. Hingga kemudian tren membuat Yiming memutuskan untuk merambah aplikasi media sosial yang lebih interaktif.

Dalam industri konten, teks dan gambar telah berkembang menjadi video, dan konten kini banyak berasal dari pengguna. Perubahan lakukan untuk menjawab kebutuhan pengguna tik tok itu sendiri. ByteDance kemudian mengembangkan TikTok yang merupakan aplikasi pembuat video pendek.

Aplikasi yang di negara asalnya dikenal dengan nama Douyin ini secara resmi pada September 2016. Sepanjang tahun 2018, aplikasi tersebut merajai App Store dengan 500 juta kali unduhan lebih. Sebagian besar pengguna TikTok diketahui merupakan anak muda danbahkan yang masih belia. ${ }^{6}$ Namun ada beberapa manfaat yang bisa didapatkan dari aplikasi ini untuk berbagai hal, seperti:

\footnotetext{
${ }^{5}$ Rhendi Umar, "SEJARAH Aplikasi Video TikTok, Diciptakan Oleh Pria Asal China, Bermula Dari Ajang Seru-Seruan,” Tribun Manado, n.d., https://manado.tribunnews.com/2020/02/16/sejarah-aplikasi-videotiktok-diciptakan-oleh-pria-asal-china-bermula-dari-ajang-seru-seruan.

${ }^{6}$ Umar.
} 


\section{a. Bisnis}

Aplikasi TikTok ini bisa digunakan untuk mempromosikan bisnis serta brand . Konten-konten dari TikTok bisa digunakan untuk membangun brand image yang bagus bila dioptimasi dengan baik dan benar.

Anda bisa membuat akun serta konten - konten TikTok sendiri dan menggunakannya sebagai sarana promosi ataupun cara membangun brand image bisnis. Cara lainnya adalah dengan bekerja sama dengan para influencer TikTok yang sudah memiliki audiens mereka masing - masing.

\section{b. Personal Brand}

TikTok juga bisa Anda gunakan untuk membangun brand personal Anda. Bila seorang influencer ataupun ingin menjadi seorang influencer, TikTok bisa menjadi tempat yang cocok untuk memulai. Popularitas dan jumlah pengguna yang banyak akan bisa menjadi sebuah potensi.

Menjadi influencer di TikTok juga bisa menjadi sumber income yang baik. Akan ada banyak tawaran daribrand - brandyang ingin menggunakan jasa sebagai seorang brand influencer.

\section{c. Hiburan}

TikTok juga bisa menjadi tempat bagi Anda untuk mencari hiburan yang menarik. Ada banyak konten - konten lucu serta menarik yang bisa digunakan sebagai stress relief Anda. Anda juga bisa membuat video - video yang lucu dan menarik sebagai cara untuk menghibur diri Anda serta orang -orang lain.

\section{Tik tok dan Dakwah}

Salah satu sosok yang kini menjadi viral berkat TikTok adalah seorang gadis bernama Zahra Hashimee. Zahrah tidak hanya senang-senang menggunakan tiktok, hijabers yang tinggal di Albany, New York tersebut rupanya juga membagikan beberapa pesan soal agama lewat TikTok. Sosok Zahra Hashimee mulai viral tahun lalu saat dirinya iseng membuat video TikTok bersama teman-temannya. Dari sanalah, Zahra Hashimee menjadi terkenal. Dalam kurun waktu setahun, Zahra berhasil mendapatkan 1,8 juta pengikut di akunnya yang bernama @muslimthicc. Bukan hanya 
video bersama teman-temannya, Zahra juga mulai membagikan video seputar diskusi agama Islam. Bahkan, beberapa videonya saat berbicara agama Islam menjadi populer. Lewat TikTok, Zahra banyak membicarakan miskonsepsi tentang Muslim hingga menjelaskan hal-hal seperti bulan Ramadan. ${ }^{7}$

Selain itu, Zahra juga membuat video soal tutorial hijab hingga beberapa keuntungan menggunakan hijab namun dengan gaya kocak. "Kontenku sebagian besar hanyalah tentangku menjadi diri sendiri di depan kamera. Aku hanya berbicara tentang hal-hal random yang terjadi padaku, melakukan hal bodoh dengan temanteman, atau bersiap-siap menjalani hari," Namun, Zahra berusaha untuk terus membagikan konten yang positif serta sesuai dengan umur para pengikutnya yang kebanyakan masih remaja. Dia selalu mencoba untuk menjadi ramah kepada orangorang, dan dia juga mencoba untuk menunjukkannya lewat TikTok. Ini seperti, hei, jadilah orang yang positif, bahagia, dan baik. Dia harap orang-orang menangkap pesan itu," Zahra Hashimee sendiri kini adalah mahasiswi di University of Albany di jurusan Ilmu Komputer.

Sehingga dapat disimpulkan bahwa penggunaan tiktok bukan hanya sekedar goyang atau hal lainnya namun bisa kita gunakan dengan berbagi ilmu pengetahuan terutama dalam islam.

\section{METODE PENELITIAN}

Penelitian kualitatif bertujuan mencari pengertian mendalam tentang suatu gejala fakta atau realita. Fakta, realita, masalah, gejala serta peristiwa hanya dapat dipahami bila peneliti menelusurinya secara mendalam dan tidak di permukaan saja. Landasan teori dimanfaatkan sebagai pemandu agar fokus penelitian dengan fakta dilapangan. Serta menggunakan metode dari rujukan jurnal terdahulu.

\section{PEMBAHASAN DAN HASIL}

\section{Pemanfaatan Tik Tok Sebagai Media Komunikasi}

Komunikasi dalam bahasa inggris communicationberasal dari kata latin communicatio dan berasal dari kata communis yang berarti sama. Media komunikasi

\footnotetext{
${ }^{7}$ Aldi fatriadi, "Perspektif Dakwah Islam Dalam Penggunaan Aplikasi Tiktok Dimasa Pandemi Covid-19," 2020, https://doi.org/10.31219/osf.io/58g4e.
} 
adalah suatu alat atau sarana yang digunakan untuk menyampaikan pesan dari komunikator kepada khalayak. Media dominan dalam berkomunikasi adalah pancaindera manusia seperti telinga dan mata.Media juga merupakan jendela yang memungkinkan kita untuk dapat melihat lingkungan yang lebih jauh, sebagai penafsir yang membantu memahami pengalaman,Sebagai landasan penyampai informasi, Sebagai komunikasi interaktif yang meliputi opini audiens, Sebagai penanda pemberi intruksi atau petunjuk, Sebagai penyaring atau pembagi pengalaman dan fokus terhadap orang lain, cermin yang merefleksikan diri kita dan penghalang yang menutupi kebenaran. Media komunikasi juga dijelaskan sebagai sebuah sarana yang dipergunakan sebagai memproduksi, reproduksi, mengolah dan mendistribusikan untuk menyampaikan sebuah informasi. Media komunikasi sangat berperan penting bagi kehidupan masyarakat. ${ }^{8}$

Secara sederhana, sebuah media komunikasi adalah sebuah perantara dalam menyampaikan sebuah informasi dari komunikator kepada komunikan yang bertujuan agar efisien dalam menyebarkan informasi atau pesan. Komunikasi merupakan bentuk percakapan yang berlangsung atas dasar persamaan persepsi.

Tik tok sebagai media jejaring social, menjadi salah satu media komunikasi yang popular. Seperti yang dikemukakan oleh Fauziyah dosen prodi KPI menyatakan bahwa Tik tok merupakan salah satu platform yang mampu memberikan informasi up to date dengan cara yang menyenangkan.

Ketertarikan seseorang dalam menggunakan Tik tok sebagai media komunikasi salah satunya karena kepopuleran media ini dan ketersediaan informasi yang banyak ditemukan oleh orang-orang yang mencari informasi. Minat terhadap fitur tik tok juga menjadikan media ini sebagai alat komunikasi. Seperti halnya yang diungkapkan Alfian dosen prodi KPI yang menyatakan bahwa video yang berdurasi pendek akan memberikan pemahaman yang maksimal jika konten yang disusung tentang pengetahuan mengingat budaya short attention dari masyarakat saat ini. Keterangan

\footnotetext{
${ }^{8}$ Gun Gun Heryanto, Media Komunikasi Politik (IRCiSoD, 2018).
} 
keterangan tersebut dapat disimpulkan bahwa tik tok sebagai media social yang dijadikan banyak orang untuk berkomunikasi dalam berbagai factor.

\section{Pemanfaatan Tik tok sebagai media dakwah islam}

Dakwah dengan berbagai dinamika yang melingkupinya memerlukan kreativitas dan inovasi yang disesuaikan dengan perkembangan zaman yang ada. Konsep al Islamu sholih likulli zaman wa makan (Islam sesuai dengan kondisi waktu dan tempat) merupakan prinsip yang dipegang para da'i dalam mengemban tugas sucinya. ${ }^{9}$ Keindahan Islam yang tersurat dan tersirat indah dalam alquran dan al hadits hanya akan menjadi tanda-tanda kekuasaan Tuhan yang "tersembunyi" apabila tidak dapat dipahami dan diamalkan dalam mad'u dakwah.

Akses dan pemahaman terhadap sumber-sumber teknologi yang ada perlu menjadi perhatian para da'i. Para komunikator Islam tidak hanya perlu menguasai ilmu agama, dan ilmu umum untuk mengkompilasi muatan Islam yang akan disampaikan, tetapi juga media yang merupakan sarana efektif dalam menunaikan tugas mulia dakwah. Salah satu teknologi yang menjadi trend masyarakat dewasa ini adalah internet.

Seperti yang dinyatakan Khoirul Kaprodi Manajemen Pendidikan Islam bahwa tik tok memiliki peluang untuk menciptakan literasi khasanah keilmuan tentang agama Islam yang sangat diperlukan oleh masayarakat luas dengan disajikan sesuai dengan pola hidup masyarakat sekarang yang tidak bisa jauh dari smartphone.

Yang mendasari orang-orang memilih aplikasi tik tok karena ingin berbagi keilmuan tentang Agama Islam. Agar Ilmu yang disampaikan membawa dampak yang luas bagi para pengguna plaform ini.

Fakta fakta tersebut menunjukkan bahwa Berkaitan dengan dakwah di dunia maya, Islam sebagai agama yang responsif terhadap segala perubahan dan keadaan, sudah selayaknya melakukan evaluasi terhadap "dakwah tradisional" yang dilakukan selama ini. Dakwah dalam arti yang luas (bukan sekedar tabligh atau ceramah) dituntut untuk mampu menembus dunia cyber dalam rangka menebarkan benih-benih nilai nilai mulia Islam.

\footnotetext{
9 Adi Wibowo, "Penggunaan Media Sosial Sebagai Trend Media Dakwah Pendidikan Islam Di Era Digital," Jurnal Islam Nusantara 3, no. 2 (2019): 339-56.
} 


\section{Perkembangan Media Tik tok sebagai media dakwah dikalangan Dosen IAI}

\section{Sunan Kalijogo Malang}

Dalam mengembangkan Tik tok sebagai media Dakwah sebagaimana yang dikembangkan oleh Atik Kaprodi Pendidikan Bahasa Arab yang juga memiliki tiktok yang bernama @Anasahchannel Ia juga menggunakan aplikasi tiktok untuk berbagi pesan dakwah bukan seperti pengguna lainnya. Dengan pengikut 3797 penulis sering membagikan pesan dakwah atau sejarah Islam, pesan tersebut dikemas dalam bentuk video berdurasi pendek dan diiringi sholawat atau lagu islami. Disini penulis ingin memperlihatkan bahwa penggunaan tiktok bukan hanya sekedar goyang atau hal lainnya namun bisa kita gunakan dengan berbagi ilmu pengetahuan terutama dalam islam.

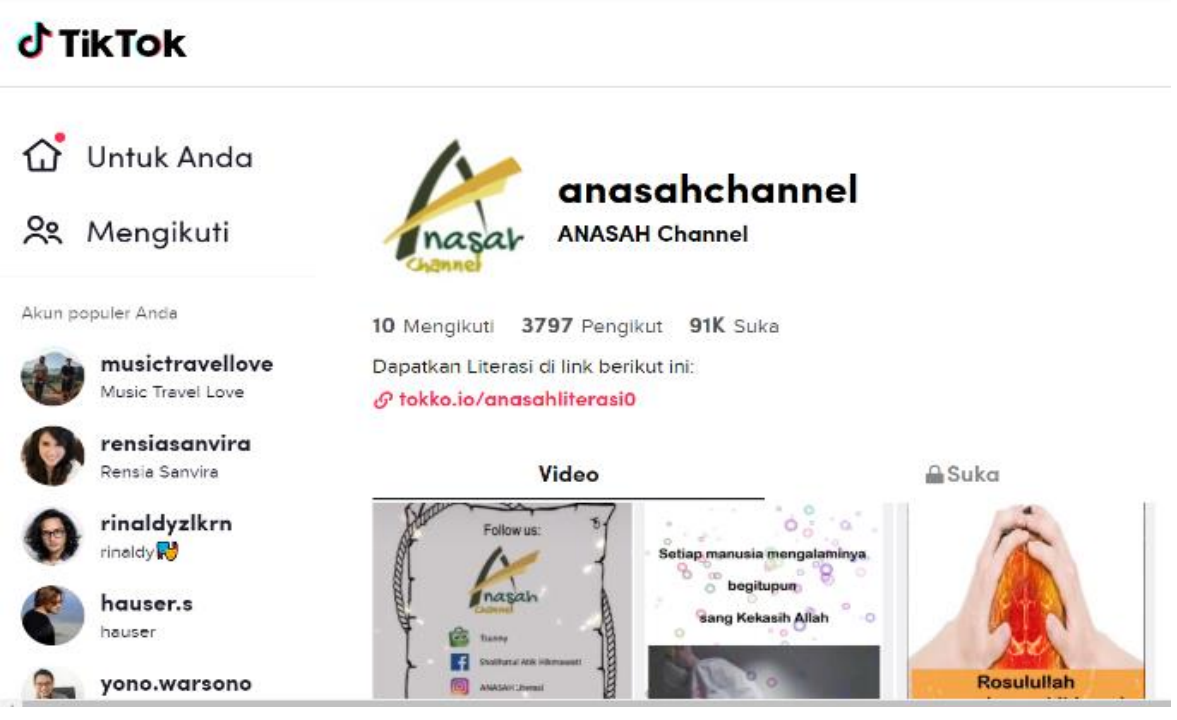

Gambar1.1@anasahchannel oleh Dosen

Informasi tersebut menjelaskan bahwa masyarakat atau Mad'u memberikan tanggapan yang positif terkait media dakwah menggunakan media sosial, indikasi trend media sosial sebagai media dakwah menunjukan perkembangan dakwah yang semakin fleksibel dan dinamis dan diyakini trend dakwah ini akan terus berkembang pada masyarakat modern mengikuti trend media-media baru yang kemudian akan dijadikan media dakwah yang relevan, sesuai dengan kebutuhan masyarakan yang hidup dizaman ini. 


\section{KESIMPULAN}

Dapat penulis simpulkan bahwa penggunaan media social salah satunya adalah Tik tok dalam media dakwah yang dikembangkan oleh sebagian Dosen IAI Sunan Kalijogo Malang mendapatkan respon positif, serta menyampaikan pesan yang bisa diterima oleh semua khalayak umum baik anak-anak, remaja, dewasa sampai orang tua karena konten yang disajikan mengandung nilai nilai pendidikan Islam yang berhaluan ahlusunnah wal Jama'ah sehingga dapat dijadikan pedoman, motivasi serta informasi untuk menjalani kehidupan sehari-hari.

Dosen dosen IAI Sunan Kalijog Malang berupaya mengaktualisasi pesan-pesan diatas guna memberikan informasi keagamaan melaui media sosial kepada masyarakat melalui media sosial tik tok dengan demikian tidak diragukan lagi bagaimana media sosial memberikan ruang publik yang sangat besar Penggunaan media sosial juga sebagai media informasi yang dimanfaatkan oleh masyarakat secara luas. 


\section{DAFTAR PUSTAKA}

Deslima, Yosieana Duli. "Pemanfaatan Instagram Sebagai Media Dakwah Bagi Mahasiswa Komunikasi Dan Penyiaran Islam UIN Raden Intan Lampung." UIN Raden Intan Lampung, 2018.

Fatriadi, Aldi. "Perspektif Dakwah Islam Dalam Penggunaan Aplikasi Tiktok Dimasa Pandemi Covid-19," 2020. https://doi.org/10.31219/osf.io/58g4e.

Hanika, Ita Musfirowati. "Fenomena Phubbing Di Era Milenia (Ketergantungan Seseorang Pada Smartphone Terhadap Lingkungannya)." Interaksi: Jurnal Ilmu Komunikasi 4, no. 1 (2015): 42-51.

Heryanto, Gun Gun. Media Komunikasi Politik. IRCiSoD, 2018.

Pimay, Awaludin. Paradigma Dakwah Humanis: Strategi Dan Metode Dakwah Prof. KH Saifuddin Zuhri. RaSAIL, 2005.

Thoharoh, Dewi. "Strategi Dakwah M. Quraish Shihab Dalam Buku" Membumikan AlQur'an".” IAIN Walisongo, 2010.

Umar, Rhendi. "SEJARAH Aplikasi Video TikTok, Diciptakan Oleh Pria Asal China, Bermula Dari Ajang Seru-Seruan." Tribun Manado, n.d. https://manado.tribunnews.com/2020/02/16/sejarah-aplikasi-video-tiktokdiciptakan-oleh-pria-asal-china-bermula-dari-ajang-seru-seruan.

Wibowo, Adi. "Penggunaan Media Sosial Sebagai Trend Media Dakwah Pendidikan Islam Di Era Digital." Jurnal Islam Nusantara 3, no. 2 (2019): 339-56. 